\title{
CD72 wt Allele
}

National Cancer Institute

\section{Source}

National Cancer Institute. CD72 wt Allele. NCI Thesaurus. Code C51130.

Human CD72 wild-type allele is located in the vicinity of 9p13.3 and is approximately $8 \mathrm{~kb}$ in length. This allele, which encodes B-cell differentiation antigen CD72 immunoprotein, is involved in the regulation of mature $B$ cell proliferation and differentiation. 